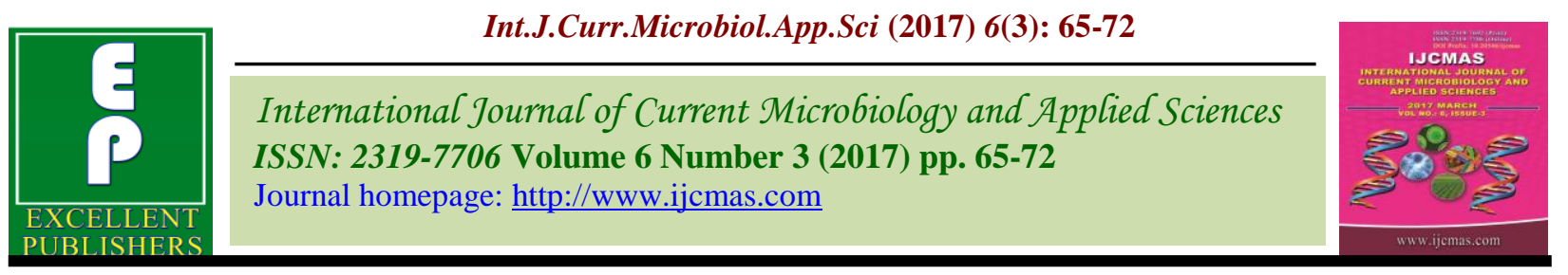

Original Research Article

https://doi.org/10.20546/ijcmas.2017.603.006

\title{
Effect of Weed Management Practices and Establishment Methods on Growth, Productivity and Economics of Rice
}

\author{
Rajiv Dubey $^{1 *}$, Dheer Singh ${ }^{2}$ and Aakash Mishra ${ }^{3}$ \\ ${ }^{1}$ Department of Agronomy, College of Horticulture, Mandsaur (M.P.), India \\ ${ }^{2}$ Department of Agronomy, College of Agriculture, GBPUA\&T, Pantnagar (U.K.), India \\ ${ }^{3}$ AICRP- Weed Management, B.A. College of Agriculture, Anand Agriculture University, \\ Anand 388110, Gujarat, India \\ *Corresponding author
}

\begin{tabular}{|c|c|}
\hline & A B S T R A C T \\
\hline & \multirow{6}{*}{$\begin{array}{l}\text { A field experiment was conducted at N.E. Borlaug Crop Research Centre of Govind } \\
\text { Ballabh Pant University of Agriculture and Technology, Pantnagar, U.S. Nagar } \\
\text { (Uttarakhand) during Kharif seasons of } 2010-11 \text { and } 2011-12 \text { to study the effect of } \\
\text { crop establishment methods and weed management practices on growth and } \\
\text { productivity of rice. Four crop establishment method viz. system of rice intensification } \\
\text { (SRI), transplanted rice (TPR), direct seeded rice (DSR-dry seeded) and wet seeded } \\
\text { rice (WSR- sprouted) and four weed management practices viz. pyrazosulfuron-ethyl } \\
\text { ( } 3 \text { DAS/DAT) + mechanical weeding (at } 40 \text { DAS/DAT), cono-weeder (twice- at } 20 \\
\text { and } 40 \text { DAS/DAT), hand-weeding (twice- at } 20 \text { and } 40 \text { DAS/DAT) and weedy check } \\
\text { were tested in strip plot design with three replications. Maximum shoot dry matter, } \\
\text { higher number of panicles, grains per panicle, longer panicle length, test weight, grain } \\
\text { yield and net return was recorded in hand weeding ( } 20 \text { and } 40 \text { DAS/DAT) than that of } \\
\text { other weed management practices. Among the rice establishment methods, SRI } \\
\text { method exhibited maximum grains per panicle, longer panicle length, test weigh, grain } \\
\text { yield and harvest index and net return. }\end{array}$} \\
\hline Keywords & \\
\hline $\begin{array}{l}\text { SRI, Wet seeded } \\
\text { rice, Cono-weeder, } \\
\text { Pyrazosulfuron- } \\
\text { ethyl. }\end{array}$ & \\
\hline Article Info & \\
\hline $\begin{array}{l}\text { Accepted: } \\
\text { 08 February } 2017 \\
\text { Available Online: } \\
10 \text { March } 2017\end{array}$ & \\
\hline & \\
\hline
\end{tabular}

\section{Introduction}

Rice (Oryza sativa L.) is the predominant staple food for more than half of the world population because of its caloric contribution and monetary benefits. Diseases, insects and weeds are the major barriers for lower productivity of rice among weeds is a prominent one. Weeds are at present, the major biotic constraint to impede rice production worldwide. Weeds compete with rice for sunlight, nutrients, space and water and reduce the yield. Inadequate weed control in rice may cause yield reduction up to 65 per cent (Yaduraju et al., 2006) and proper weed management in rice have also been emphasized by several others (De Datta and Baltazar, 1996; Zhang, 1996). Weed infestation is regarded as one of the major causes of low crop yields throughout the world and can reduce 50-60\% grain yield under puddled conditions and $91 \%$ or even more yield reduction in un-puddled conditions. For better productivity of rice crop, it was reported by various workers that weeds should be removed in early stages of crop growth by any of the appropriate effective methods. No doubt hand weeding has proved to be the most effective method in controlling weeds as compared to other methods of weed 
management, even though it is tedious and highly labour intensive. Farmers very often also fail to remove weeds due to unavailability of labour at required stages. Moreover, morphological similarity between grassy weeds and rice seedlings also makes hand weeding difficult particularly at early stages of crop growth. Considering all these problems, herbicide is being considered as the most practical, effective and economical tools of weed management in rice and nowadays herbicides are becoming popular among the farmers (Barman and Varshney, 2008) but any single approach i.e. either use of herbicides or mechanical weeding is not convenient in controling the weeds. Thus, integration of chemical and mechanical methods may provide effective control of weeds. Rice is cultivated with various methods and practices.

The aerobic rice (SRI), drum seeding, direct seeding unpuddled, direct seeding puddled and transplanted rice are the methods of rice cultivation in the plain, hill, saline-alkali, deep water etc. ecosystems. Transplanting and direct seeding are two common methods for rice planting in the world. Although transplanting is more common but it is more labour consuming, cumbersome, time consuming and entails a lot of expenditure on raising nursery, its uprooting and transplanting, etc. (Pandey et al., 2002; Dawe, 2005; Tuong et al., 2005). Direct seeding of rice has several advantages over transplanted rice (Singh et al., 2005). Depending on the nature of the production system, direct seeding can reduce the labour requirement as much as $50 \%$. In addition to higher economic returns, direct seeded rice crops are faster and easier to plant and consume less water (Khade et al., 1993; Santhi et al., 1998; Pandey and Velasco, 1999; Balasubramanian and Hill, 2002; Jehangir et al., 2005). Direct seeded rice has received much attention because of its low-input demand (Farooq et al., 2011). In some studies under proper cultural practices, direct seeding significantly outyielded the transplanted rice. Increasing water scarcity is becoming a real threat to rice cultivation and water saving technology needs to be developed. SRI method has been found to save 22 and 38 per cent water, respectively during dry and wet season over conventional method (Viraktamath et al., 2007). With this background, the present study was undertaken to study the effect of weed management practices and establishment methods on crop growth, productivity and profitability of rice.

\section{Materials and Methods}

The study was undertaken during Kharif season of 2010 and 2011 at N.E. Borlaug Crop Research Centre of Govind Ballabh Pant University of Agriculture and Technology, Pantnagar, U.S. Nagar (Uttarakhand) India. The soil of the experimental site was loam in texture with neutral $\mathrm{pH}$ having $0.87 \%$ organic carbon (modified Walkley and Black method), $217.48 \mathrm{~kg} / \mathrm{ha}$ available $\mathrm{N}$ (by microKjeldahl method), $21.36 \mathrm{~kg} / \mathrm{ha}$ available $\mathrm{P}$ (Olsen's method) and $142.37 \mathrm{~kg} / \mathrm{ha}$ available $\mathrm{K}$ (by flame emission spectrophotometry method). The experiment comprising Four crop establishment method viz. system of rice intensification (SRI), transplanted rice (TPR), direct seeded rice (DSR-dry seeded) and wet seeded rice (WSR- sprouted) and four weed management practices viz. Pyrazosulfuronethyl (3 DAS/DAT) + mechanical weeding (at 40 DAS/DAT), cono-weeder (twice- at 20 and 40 DAS/DAT), hand-weeding (twice- at 20 and 40 DAS/DAT) and weedy check and were tested in strip plot design with three replications. Pre-germinated seeds of cv. NDR-359 were used in nursery. Recommended practices were adopted for nursery raising. In case of transplanted rice, seedling was transplanted manually in the rows with the help of nylon rope at $20 \mathrm{~cm} \mathrm{x}$ $15 \mathrm{~cm}$ spacing using 2-3 seedlings per hill. In 
SRI 10 day's old seedling were used for transplanting. Single seedling with seed and soil was transplanted by using index finger and thumb and gently planting them at the intersection of marking $25 \mathrm{cmx} 25 \mathrm{~cm}$ in puddled soil. A week after transplanting, gap filling was done. In direct seeded and wet seeded rice seeds were sown in lines, $20 \mathrm{~cm}$ apart at $40 \mathrm{~kg} \mathrm{ha}^{-1}$. The experimental crop was fertilized with 150: $60: 40 \mathrm{~kg} \mathrm{ha}^{-1}$ of $\mathrm{N}, \mathrm{P}$ and $\mathrm{K}$ respectively. In all the establishment methods except SRI, nitrogen was applied through NPK mixture (12:32:16) and rest amount of nitrogen through urea. The total amount of phosphorus was applied through NPK mixture (12:32:16) and potassium was applied through NPK mixture (12:32:16) and rest amount through muriate of potash (MOP). Full quantity of phosphorus and potassium and one third of nitrogen was applied just before sowing of rice seed. Remaining Remaining half of the nitrogen was top dressed through urea in two splits; first at active tillering and second at panicle initiation stage.

In SRI method the soil was kept moist upto panicle initiation then flooded after panicle initiation. Irrigations of $2-3 \mathrm{~cm}$ water were given after appearing of hair like crack upto reproductive phase then $5 \mathrm{~cm}$ water was stagnated upto crop maturity. For other method, a thin film of $(2-3 \mathrm{~cm})$ of water was maintained during the initial stage upto seedling establishment, thereafter, the water level was gradually increased to $5 \mathrm{~cm}$ and attempts were made to maintain this level upto milk stage, after that water was reduced to saturation level and never allowed to develop cracks upto physiological maturity stage of crop. Harvesting was done manually when more than $90 \%$ of the grain in the panicle were fully riped and free from greenish tint. Net returns of each treatment were calculated by deducting the cost of cultivation from the gross returns. Benefit- cost ratio was calculated by dividing the net return into the cost of cultivation.

\section{Results and Discussion}

Among the 4 weed management practices tested, the more plant-height, number of shoots $\left(\mathrm{m}^{-2}\right)$, crop growth rate, leaf area index was recorded in hand hand-weeding (20 and 40 DAS/DAT) than other weed management practices at harvest (Table 1). Among rice establishment methods, SRI method exhibited taller plants, higher crop growth rate and leaf area index. In case of treatment combinations, at all the growth stages, SRI methods with pyrazosulfuron (3 DAT) led the highest plantheight and crop growth rate. Shoot population in transplanted rice was at par with wet seeded rice, exhibited significantly higher than that of direct seeded rice and SRI method. Among the various treatment combinations, transplanted rice with handweeding (20 and 40 DAT) led to record the higher number of shoots over rest of the treatment combinations. Similarly, hand weeding (20 and 40 DAS/DAT) gave significantly maximum shoot dry matters $\left(\mathrm{m}^{-}\right.$ ${ }^{2}$ ) over rest of the weed management practices at harvest stage. Transplanted rice caused significantly more shoot dry matter as compared to rest of the rice establishment methods. In case of treatment combinations, at all the growth stages, SRI method with pyrazosulfuron (3 DAT) + mechanical weeding (40 DAT) led to record the maximum shoot dry matter. Higher number of panicles, grains per panicle, longer panicle length, test weight was recorded in hand weeding (20 and 40 DAS/DAT) than that of other weed management practices (Table 2). Transplanted rice registered significantly higher number of panicles $\left(\mathrm{m}^{-2}\right)$ and SRI method exhibited longer panicle length, maximum grains per panicle and test weight than that of other rice establishment methods. 
Table.1 Effect of crop establishment methods and weed management practices on growth attributes

\begin{tabular}{|c|c|c|c|c|c|c|c|c|c|c|}
\hline \multirow[t]{2}{*}{ Treatments } & \multicolumn{2}{|c|}{ Plant-height (cm) } & \multicolumn{2}{|c|}{$\begin{array}{l}\text { Shoot dry matter } \\
\qquad\left(\mathrm{g} \mathrm{m}^{-2}\right)\end{array}$} & \multicolumn{2}{|c|}{ Number of shoots } & \multicolumn{2}{|c|}{$\begin{array}{l}\text { CGR (60-90 } \\
\text { DAS/DAT) }\end{array}$} & \multicolumn{2}{|c|}{$\begin{array}{c}\text { LAI }(60 \\
\text { DAS/DAT) }\end{array}$} \\
\hline & 2010-11 & 2011-12 & 2010-11 & 2011-12 & 2010-11 & 2011-12 & 2010-11 & 2011-12 & 2010-11 & 2011-12 \\
\hline \multicolumn{11}{|l|}{ Weed management methods $(\mathrm{W})$} \\
\hline $\begin{array}{l}\text { Pyrazosulfuron (3 DAS/DAT) +Mechanical } \\
\text { Weeding (at } 40 \text { DAS/DAT) }\end{array}$ & 103.4 & 109.3 & 965 & 1013 & 246 & 251 & 14.80 & 15.67 & 4.24 & 4.34 \\
\hline Cono-weeder (twice- at 20 and 40 DAS/DAT) & 100.4 & 103.2 & 904 & 934 & 237 & 244 & 13.50 & 14.41 & 4.09 & 4.27 \\
\hline Hand-weeding (twice- at 20 and 40 DAS/DAT) & 109.9 & 113.6 & 1031 & 1062 & 250 & 259 & 16.61 & 16.36 & 4.27 & 4.35 \\
\hline Weedy check & 92.4 & 96.6 & 568 & 604 & 162 & 168 & 8.44 & 8.95 & 3.10 & 3.02 \\
\hline $\mathrm{SEm} \pm$ & 4.6 & 2.8 & 9.71 & 12.79 & 4.07 & 3.16 & 0.59 & 0.52 & 0.11 & 0.11 \\
\hline $\mathrm{CD}(0.05 \%)$ & 16.1 & 9.7 & 33.65 & 44.33 & 14.08 & 10.96 & 2.03 & 1.81 & NS & NS \\
\hline \multicolumn{11}{|l|}{ Establishment methods (E) } \\
\hline System of Rice Intensification (SRI) & 107.0 & 112.1 & 968 & 993 & 188 & 197 & 14.24 & 14.93 & 4.03 & 4.17 \\
\hline Transplanted Rice (TPR) & 101.9 & 105.7 & 925 & 957 & 251 & 255 & 14.08 & 14.57 & 3.99 & 4.05 \\
\hline Direct Seeded Rice (DSR-Dry Seeded) & 97.1 & 102.4 & 709 & 768 & 219 & 224 & 10.84 & 11.20 & 3.80 & 3.85 \\
\hline Wet Seeded Rice (WSR-Sprouted) & 100.2 & 102.4 & 867 & 895 & 237 & 246 & 14.18 & 14.67 & 3.86 & 3.92 \\
\hline SEm \pm & 1.6 & 0.8 & 12.29 & 10.27 & 7.14 & 5.27 & 0.69 & 0.44 & 0.02 & 0.04 \\
\hline $\mathrm{CD}(0.05 \%)$ & 5.5 & 2.7 & 42.58 & 35.59 & 24.46 & 18.26 & 2.38 & 0.44 & NS & NS \\
\hline \multicolumn{11}{|l|}{ Interaction (WXE) } \\
\hline SEm \pm & 4.1 & 1.2 & 17.43 & 10.87 & 7.45 & 8.53 & 1.39 & 1.05 & 0.04 & 0.10 \\
\hline $\mathrm{CD}(0.05 \%)$ & 12.2 & 3.5 & 51.76 & 32.28 & 22.14 & 25.34 & 4.11 & 3.11 & NS & NS \\
\hline
\end{tabular}


Table.2 Effect of crop establishment methods and weed management practices on yield attributes and economics

\begin{tabular}{|c|c|c|c|c|c|c|c|c|c|c|c|c|c|c|c|c|c|c|}
\hline \multirow[t]{2}{*}{ Treatments } & \multicolumn{2}{|c|}{$\begin{array}{l}\text { Number of } \\
\text { panicles }\end{array}$} & \multicolumn{2}{|c|}{$\begin{array}{l}\text { Length of } \\
\text { panicles }(\mathrm{cm})\end{array}$} & \multicolumn{2}{|c|}{$\begin{array}{l}\text { Number of } \\
\text { grains per } \\
\text { panicles }\end{array}$} & \multicolumn{2}{|c|}{$\begin{array}{l}\text { Test weight } \\
\text { (g) }\end{array}$} & \multicolumn{2}{|c|}{$\begin{array}{l}\text { Grain yield } \\
\text { (q/ha) }\end{array}$} & \multicolumn{2}{|c|}{$\begin{array}{l}\text { Straw yield } \\
\text { (q/ha) }\end{array}$} & \multicolumn{2}{|c|}{$\begin{array}{l}\text { Harvest } \\
\text { index }\end{array}$} & \multicolumn{2}{|c|}{$\begin{array}{l}\text { Net Return } \\
\text { (Rs/ha) }\end{array}$} & \multicolumn{2}{|c|}{$\mathrm{B}: \mathrm{C}$ ratio } \\
\hline & $\begin{array}{l}2010- \\
11 \\
\end{array}$ & $\begin{array}{l}2011- \\
12 \\
\end{array}$ & $\begin{array}{l}2010- \\
11 \\
\end{array}$ & $\begin{array}{l}2011- \\
12 \\
\end{array}$ & $\begin{array}{l}2010- \\
11\end{array}$ & $\begin{array}{l}2011- \\
12 \\
\end{array}$ & $\begin{array}{l}2010- \\
11 \\
\end{array}$ & $\begin{array}{l}2011- \\
12 \\
\end{array}$ & $\begin{array}{l}2010- \\
11 \\
\end{array}$ & $\begin{array}{l}2011- \\
12 \\
\end{array}$ & $\begin{array}{l}2010- \\
11 \\
\end{array}$ & $\begin{array}{l}2011- \\
12 \\
\end{array}$ & $\begin{array}{l}2010- \\
11 \\
\end{array}$ & $\begin{array}{l}2011- \\
12 \\
\end{array}$ & $\begin{array}{l}2010- \\
11 \\
\end{array}$ & $\begin{array}{l}2011- \\
12\end{array}$ & $\begin{array}{l}2010 \\
-11\end{array}$ & $\begin{array}{l}2011- \\
12\end{array}$ \\
\hline \multicolumn{19}{|c|}{ Weed management methods (W) } \\
\hline $\begin{array}{l}\text { Pyrazosulfuron (3 } \\
\text { DAS/DAT) } \\
\text { +Mechanical Weeding } \\
\text { (at } 40 \text { DAS/DAT) }\end{array}$ & 239 & 246 & 27.3 & 28.0 & 85 & 95 & 27.7 & 28.1 & 4.18 & 4.44 & 5.46 & 5.69 & 0.43 & 0.44 & 30264 & 36631 & 1.31 & 1.67 \\
\hline $\begin{array}{l}\text { Cono-weeder (twice- } \\
\text { at } 20 \text { and } 40 \\
\text { DAS/DAT) }\end{array}$ & 231 & 240 & 26.9 & 27.8 & 79 & 84 & 27.3 & 27.9 & 3.91 & 4.08 & 5.13 & 5.27 & 0.43 & 0.43 & 26768 & 31918 & 1.15 & 1.45 \\
\hline $\begin{array}{l}\text { Hand-weeding (twice- } \\
\text { at } 20 \text { and } 40 \\
\text { DAS/DAT) }\end{array}$ & 244 & 250 & 27.7 & 28.0 & 90 & 100 & 27.8 & 28.2 & 4.44 & 4.67 & 5.87 & 5.95 & 0.43 & 0.44 & 30996 & 36972 & 1.20 & 1.19 \\
\hline Weedy check & 151 & 160 & 24.5 & 25.0 & 41 & 43 & 26.3 & 26.9 & 2.13 & 2.32 & 3.55 & 3.71 & 0.37 & 0.39 & 8484 & 13122 & 0.41 & 0.68 \\
\hline SEm \pm & 2.5 & 2.5 & 0.4 & 0.2 & 0.8 & 1.5 & 0.3 & 0.2 & 0.10 & 0.08 & 0.13 & 0.08 & 0.003 & 0.008 & - & - & - & - \\
\hline $\mathrm{CD}(0.05 \%)$ & 8.7 & 8.6 & 1.4 & 0.8 & 2.8 & 5.4 & NS & NS & 0.35 & 0.29 & 0.45 & 0.29 & NS & NS & - & - & - & - \\
\hline \multicolumn{19}{|c|}{ Establishment methods (E) } \\
\hline $\begin{array}{l}\text { System of Rice } \\
\text { Intensification } \\
(\mathrm{SRI})\end{array}$ & 184 & 193 & 28.4 & 29.9 & 102 & 113 & 28.0 & 28.7 & 4.49 & 4.70 & 5.16 & 5.23 & 0.45 & 0.47 & 33177 & 38797 & 1.48 & 1.82 \\
\hline $\begin{array}{l}\text { Transplanted Rice } \\
(\mathrm{TPR})\end{array}$ & 243 & 249 & 26.5 & 26.9 & 71 & 77 & 27.3 & 27.8 & 3.79 & 4.02 & 5.46 & 5.55 & 0.41 & 0.42 & 23015 & 28791 & 0.86 & 1.14 \\
\hline $\begin{array}{lr}\text { Direct } & \text { Seeded } \\
\text { Rice } & \text { (DSR-Dry } \\
\text { Seeded) } & \\
\end{array}$ & 209 & 216 & 25.6 & 26.0 & 57 & 62 & 26.6 & 27.1 & 2.82 & 3.06 & 4.27 & 4.62 & 0.40 & 0.40 & 17597 & 22880 & 0.89 & 1.19 \\
\hline $\begin{array}{l}\text { Wet Seeded Rice } \\
\text { (WSR-Sprouted) }\end{array}$ & 230 & 239 & 25.8 & 26.2 & 64 & 70 & 27.1 & 27.4 & 3.55 & 3.73 & 5.12 & 5.22 & 0.41 & 0.42 & 22724 & 28174 & 0.95 & 1.27 \\
\hline SEm \pm & 1.7 & 2.6 & 0.9 & 0.8 & 2.6 & 1.2 & 0.4 & 0.3 & 0.07 & 0.08 & 0.19 & 0.08 & 0.008 & 0.011 & - & - & - & - \\
\hline $\mathrm{CD}(0.05 \%)$ & 6.0 & 8.5 & 3.0 & 2.9 & 9.1 & 4.3 & NS & NS & $\mathrm{NS}$ & $\mathrm{NS}$ & $\mathrm{NS}$ & NS & NS & $\mathrm{NS}$ & - & - & - & - \\
\hline \multicolumn{19}{|l|}{ Interaction (WXE) } \\
\hline SEm \pm & 4.8 & 4.9 & 0.7 & 0.8 & 2.1 & 2.5 & 0.5 & 0.5 & 0.21 & 0.18 & 0.42 & 0.18 & 0.40 & 0.40 & - & - & - & - \\
\hline $\mathrm{CD}(0.05 \%)$ & 14.2 & 14.5 & NS & NS & 6.2 & 7.3 & $\mathrm{NS}$ & $\mathrm{NS}$ & NS & $\mathrm{NS}$ & NS & NS & NS & NS & - & - & - & - \\
\hline
\end{tabular}


Among the treatment combinations, transplanted rice being at par with wet seeded rice produced significantly higher number of panicles over other establishment methods under pyrazosulfuron (3 DAS/DAT) + mechanical weeding (40 DAS/DAT), conoweeder (20 and 40 DAS/DAT) and handweeding (at 20 and 40 DAS/DAT).

In treatment combinations with respect to grains per panicle, pyrazosulfuron (3 DAS/DAT $)+$ mechanical weeding (40 DAS/DAT) with SRI method and handweeding (at 20 and 40 DAS/DAT) with SRI method led to record the higher grains per panicle over other treatment combinations.

In general higher grain yield was obtained in 2011 than 2010. This might be due to favorable weather condition like more rainfall (2007 mm) was received by the crop and was evenly distributed throughout growing period in comparison to in 2010. Significant increase of grain yield in hand weeded plots might be attributed to proper weed control in this treatment which resulted in optimum tiller density, more panicle bearing tillers $\mathrm{m}^{-2}$, more number of grains panicle ${ }^{-1}$ and more 1000gain weight. Similar findings were reported by Janardhan and Muniyappa (1994), Rekha et al., (2002) and Hasanuzzaman et al., (2008). The lowest grain yield was produced by unweeded check plot which was due to increased crop-weed competition, higher weed dry matter, lowest number of panicles per square meters and test weight. SRI method led to recorded higher grain yield and harvest index than that of other rice establishment methods. This might be due to continuous and steady supply of $\mathrm{N}$ into the soil solution to meet the required nutrients for physiological processes, which in turn improved the yield.

Among the weed management practices, hand-weeding (20 and 40 DAS/DAT) led to record the highest NMR (Rs. 30996 and 36972/ha/yr), followed by pyrazosulfuron (3 DAS/DAT) + cono-weeder (40 DAS/DAT) (Rs. 30264 and 36631/ha/yr), cono-weeder (twice- at 20 and 40 DAS/DAT) (Rs. 26768 and 31918/ha/yr) and weedy check (Rs. 8484 and 13122/ha/yr). Out of 4 rice establishment methods, SRI method fetched the highest NMR (Rs. 33177 and $38797 / \mathrm{ha} / \mathrm{yr}$ ), followed by transplanted rice (TPR) (Rs. 23015 and $28791 / \mathrm{ha} / \mathrm{yr}$ ), wet seeded rice (WSRsprouted) (Rs. 22724 and 28174/ha/yr) and direct seeded rice (DSR-dry seeded) (Rs. 17597 and 22880/ha/yr). Higher income in case of SRI was due to higher grain yield and low cost of cultivation particularly in raising of seedling and seed cost and less number of irrigations.

Among the weed control treatments, the B:C: ratio was maximum with pyrazosulfuron (3 DAS/DAT) + cono-weeder (40 DAS/DAT) (1.31 and 1.67) followed by hand-weeding (20 and 40 DAS/DAT) (1.20 and 1.19), conoweeder (twice- at 20 and 40 DAS/DAT) (1.15 and 1.45$)$, and weedy check (0.41 and 0.68) in descending order. Similarly, the B:C ratio was maximum with SRI method (1.48 and 1.82) followed by wet seeded rice (WSR- sprouted) (0.95 and 1.27), direct seeded rice (DSR-dry seeded) (0.89 and 1.19) and transplanted rice (TPR) (0.86 and 1.14) in descending order. In transplanted rice cultivation, lower $\mathrm{B}: \mathrm{C}$ ratio was recorded during both the years as compared to direct seeded rice and wet seeded rice methods, this might be due to higher cost of cultivation.

It can be concluded that for better weed control and higher yield, pyrazosulfuron (3 DAT) + conoweeder (40 DAT) in SRI and hand-weeding (20 and 40 DAS/DAT) in transplanted rice, direct (dry) seeded rice and wet (sprouted) seeded rice may be advocated. Among establishment methods, SRI was the most viable establishment method followed by transplanted rice. 


\section{References}

Janardan, G. and Muniyappa, T.V. 1994. Economics of some pre-emergence herbicides in transplanted rice. Current Res. Univ. Agric. Sci., India 22(12):154-156.

Rekha, K. B., Raju, M. S. and Reddy, M. D. 2002. Effect of herbicides in transplanted rice. Indian J. Weed Sci., 34(1-2): 123-125.

Hasanuzzaman, M., Islam, Md. Obaidul and Bapari, Md. Shafiuddin. 2008. Efficacy of different herbicides over manual weeding in controlling weeds in transplanted rice. Australian J. Crop Sci., 2(1): 18-24.

Viraktamath, B.C. 2007. Research on system of rice intensification initial experiences. In: Second National Symposium on System of Rice Intensification (SRI) in India Progress and prospects. Oct 3-5, Agartala, Tripura. pp. 28-32.

Jehangir W.A., Masih, I., Ahmed, S., Gill, M.A., Ahmad, M., Mann, R.A., Chaudhary, M.R. and Turral, H. 2005. Sustaining crop water productivity in rice-wheat systems of South Asia: a case study from Punjab Pakistan. In: Draft Working Paper. Inter. Water Management, Ins. Lahore, Pakistan.

Farooq, M., Siddique, K.H.M., Rehman, H, Aziz, T., Lee, D.J. and Wahid, A. 2011. Rice direct seeding: Experiments, challenges and opportunities. Soil. Till. Res., 111: 87-98.

Balasubramanian, V. and Hill, J.E. 2002. Direct seeding of rice in Asia: emerging issues and strategic research needs for the 21st century. In: Pandey S, Mortimer M, Wade L, Tuong TP, Lopez K, Hardy B (eds), Direct Seeding: Research Strategies and Opportunities. Inter. Rice Res. Inst. Los Baňos, Philippines, pp. 15-42.
Pandey, S. and Velasco, L.E. 1999. Economics of alternative rice establishment methods in Asia: a strategic analysis. In: Social Sciences Division Discussion Paper, International Rice Research Institute, Los Baňos, Phillipines.

Santhi, P., Ponnuswamy, K. and Cheety, N.K. 1998. Effect of seeding methods and efficient nitrogen management practices on the growth of lowland rice. $J$. Ecobiol., 10: 123-132.

Khade, V.N., Patil, B.D., Khanvilkar, S.A., and Chavan, L.S. 1993. Effect of seeding rates and level of $\mathrm{N}$ on yield of direct-seeded (Rahu) summer rice in Konkan. J. Maharash. Agric. Univ., 18: 32-35.

Pandey, S., Mortimer, M., Wade, I., Tuong, T.P., Lopez. K. and Hardy B. 2002. Direct seeding: research strategies and opportunities. IRRI International Rice Research Institute, p. 383.

Dawe, D. 2005. Increasing water productivity in rice-based systems in Asia: past trends, current problems, and future prospects. Plant Prod. Sci., 8: 221-230.

Yaduraju, N.T., Prasad Babu, M.B. and Chandla, B. 2006. Herbicide use in agriculture and environment. Swaminathan, M.S. and Chadha, K.L. (Eds.). Malhotra Publishing House, New Delhi, India. 192-210.

De Datta, S.K. and A. Baltazar. 1996. Weed control technology as a component of rice production systems. In: B. Auld and K. U. Kim (eds.) Weed Management in Rice. FAO Plant Production and Protection Paper No. 139. pp. 25-52.

Zhang, Z.P. 1996. Weed management in transplanted rice. In: B. Auld and K.U. Kim (eds.) Weed management in rice. FAO Plant Production and Protection Paper No. 139: pp. 75-86.

Barman, K.K. and Varshney J.G. 2008. Impacts of herbicide on soil 
environment. Indian J. Weed Sci., 40(1\&2): 10-17.

Pandey, S., Mortimer, M., Wade, I., Tuong, T.P., Lopez. K. and Hardy, B. 2002. Direct seeding: research strategies and opportunities. IRRI International Rice Research Institute, p. 383.

Dawe, D. 2005. Increasing water productivity in rice-based systems in Asia: past trends, current problems, and future prospects. Plant Prod. Sci., 8: 221-230.

Tuong, T.P., Bouman, B.A.M. and Mortimer,
M. 2005. More rice, less water integrated approaches for increasing water productivity in irrigated ricebased systems in Asia. Plant Prod. Sci., 8: 231-241.

Singh, Virendra, P., Singh, Govindra and Singh, Mahendra. 2005. Effect of bensulfuron-methyl (Londex $60 \mathrm{DF}$ ) on sedges and non-grassy weeds in transplanted rice. Indian J. Weed Sci., 37(1\&2): 40-44.

\section{How to cite this article:}

Rajiv Dubey and Dheer Singh. 2017. Effect of Weed Management Practices and Establishment Methods on Growth, Productivity and Economics of Rice. Int.J.Curr.Microbiol.App.Sci. 6(3): 65-72. doi: https://doi.org/10.20546/ijcmas.2017.603.006 